\title{
Media Learning in Digital Era
}

\author{
Akrim \\ University of Muhammadiyah Sumatera Utara \\ akrimmpd@yahoo.com
}

\begin{abstract}
In the digital era, the world of education must be adapted, especially the media of learning. There are some current problems when the teacher delivers the subject materials to the students, but the students are sometimes saturated and seemingly not serious about following the subject materials. One of them is that the teacher is not maximal in preparing the learning media. Teachers should make media learning interesting and tailored to the era. The instructional media designed and created by the teacher will make the students eager to learn and serious in receiving subject materials.
\end{abstract}

\section{Keywords: Learning Media and the Digital Age}

\section{INTRODUCTION}

What happens if learning process is mistaken and ineffectives to teaching process? It will take a lot of time, energy and cost while learning goals cannot be achieved and misunderstanding will occur between teachers and students. Sometimes, the teachers are not creative to use teaching methods. They are quite satisfied with conventional methods so that the students are less motivated in learning process. They rely on lecturing method so that the teaching and learning process in the classroom is very boring. The cases above are still often found in the learning process until now [1].

As the result, the students will feel bored during process of teaching and learning. They feel the school is like a prison because it cannot bring the spirit of learning. Moreover, many students are often truant, without feeling guilty. This phenomenon causes the students as an object or robot who must be fulfilled with various materials, so the students will not enjoy in the class. Meanwhile, good teaching process is when the students are not only as objects, but also as subjects. For this reason, students will be more active so that they will be motivated to join the learning process and understand the teacher explanation.

In educating the students, it must be adapted to their age phase. The process of teaching and learning will be effective and successful if the teacher is able to create learning media suitable to the material and age level of students. Study is a complex process that occurs in every person throughout their life. The learning process occurs because of the interaction between people and their environment [2].Therefore, learning can happen anytime and anywhere. One sign that someone has learned is a change in their behavior that may be caused by a change in his level of knowledge, skill or attitude. The interactions that occur during the learning process are influenced by the environment, which include students, teachers, librarians, principals, lesson materials (books, modules, magazines, video or audio recordings, etc.), and various learning resources and facilities (overhead projectors, radio, television, computers, libraries, etc.).

The Teachers are no longer reasoned if the learning media are not important in the process of teaching and learning in the class. That is why the teacher must create creative and innovative learning media that can be used in delivering the message of the subject to the students. Having the right learning media can increase the interaction between teachers and students so that students will not be bored to join the lesson. Otherwise, students are also happy with the learning media because the media can optimize the quality of students. The proper learning media in teaching and learning process will produce a satisfactory output including the change in the behavior of students.

Using the right media in delivering the subject will give good results. In the age of the digital era, the teachers must have creative ideas related to learning media. The success will be achieved when the students receive easily information of subject materials.

\section{METHOD}

Learning Media are divided into two words: learning and media. The word media comes from the Latin medius which literally means middle, intermediate or introduction. In Arabic, media are the intermediary or messenger of the sender to the recipient of the message [3]. According to Gerlach and Ely quoted by Arsyad, media in general are human, material and events that build conditions to make students able to acquire knowledge, skills or attitudes. The term of media comes from Latin medius meaning middle, intermediary, or introduction. In Arabic, media are (intermediary or messenger of the sender to the recipient of the message [4]. Media as a tool makes teachers easy to deliver messages from subject materials to students.

According to [5] the term of media which comes from Latin and the plural is medium, media literally mean intermediary or introduction. The general meaning is anything that can channel information from information sources to the recipient information. Teaching and learning process is basically also a communication process, so the media used in learning are called learning media. Learning media are part of a learning resources that are a combination of software (learning materials) and hardware (learning tools).

By learning media, the teachers will not find difficulty in conveying the message of the subject materials and the students feel more effective to receive 
the messages. While learning or phrasing that is more familiar before "teaching" is an attempt to teach the students [6]. [7] Said that learning is a combination that consists of human elements, materials, facilities, equipment and procedures that affect each other to achieve the goal of learning. Furthermore, Hamalik distinguishes the meaning of media into two: in a narrow sense and in a broad sense. In a narrow sense, teaching media only include media that can be used effectively in a planned teaching process. Whereas, in a broad sense, media do not only include complex electronic communication media, but also simple tools, such as slides, photography, diagrams, and teacher-made charts, real objects, and study excursion. In line with that view, teachers are also considered as presentation media, in addition to radio and television because they both need and use a lot of time to convey information to students. Meanwhile, according to the Big Indonesian Dictionary, learning is a process and way to make people or human beings want to learn [8]. The role of teachers to develop media is very influential to influence the learning process because basically teachers' personality has relationships with students. The competency to teach and care to the skills of the students can also influence the learning process. A teacher who is unable to explain well and lack of the subject materials understanding will affect to a lack of encouragement to the students [9]. Therefore, in the technology advancement era, teachers are not enough with a usual ability only.

Learning media are intermediary conveying subject materials to students by using certain tools so that students can understand quickly and receive knowledge from educators. To make learning media, it needs a creativity and innovation from educators. Creative and innovative learning media will create students' passion in learning. A teacher must be well-prepared for a new movement and must educate the students based on their era.

\section{Type of Learning Media in Digital Age}

The types of learning media in the digital era are firstly choosing visual aids that become learning media on subjects to be adjusted because if the learning media are not appropriate to deliver the materials, it will certainly make the process of learning in the class ineffective. A teacher must choose the right learning media with the subject materials. Secondly, use the powerpoint to help convey the subject materials. Powerpoint is not only useful to struggle in the process of making a presentation, but also to simplify the process of setting and printing presentation slides and making presentation materials in both hardcopy and softcopy. Powerpoint allows users to insert sound, image and video media into the presentation so that the presentation looks more intresting. By using Powerpoint, we can convey some important points in a seminar discussion so that seminar participants can find out the theme framework of the seminar easily. In addition to help deliver the materials presentation, how to create a
Powerpoint is also quite easy. Third, in the digital era, online-based learning systems increasingly are in demands. Edmodo is a learning platform with social network-based which is developed by Nig Borg and Jeff O'Hara at the end of 2008. How to create an Edmodo account is also quite easy because this platform is purposely intended for students, teachers and parents so that they can do the learning process easily, efficienty and fun. It can be said that Edmodo is an e-learning program that provides an easy and inexpensive way to build a virtual classroom with a class division like a real class in school. To access the Edmodo features, of course, every user must know the steps how to create an Edmodo account for learning in the classroom. Fourth, online learning site for online learning media during classroom teaching and learning activities. For example, Indonesian Ministery of Education and Culture (KEMDIKBUD) launched Rumah Belajar (Online Learning Media Portal). On this online learning site, there are a variety of learning resources ranging from electronic school books (BSE), practice training banks, online laboratory activities, visual media of Indonesian cultural maps, space exploration simulations, sustainable professional development guidance materials, to online group learning activities. In addition to utilize this educational website as a medium of learning, teachers can also contribute to create online learning media that will be posted on Rumah Belajar. Fifth, E-dukasi.Net (Junior-Senior High School Online Learning Site). EDukasi Net is one of the pioneers of online learning sites in Indonesia. Lots of online resources and learning media are available here, ranging from a collection of ebook lessons, educational video animation, to the exercise questions that we can access.

\section{Benefits of Learning Media in Digital Age}

In digital era, teachers must be able to use not only classical but also modern learning media. It will be useful for students who receive the subject materials. The benefits of learning media, Kemp and Dayton [10] suggested some research results that show the positive impact of media used as an integral part of classroom learning or as the main way of direct learning which are as follows:

Submission of learning becomes more standard

Learning process can be more interesting

Learning process becomes more interactive

The length of time required for learning can be shortened

The quality of learning outcomes can be improved

Learning process can be given whenever desired or needed

Positive attitudes of students to what is learned

The teacher's role can change towards a more positive one.

The facilities are tools, methods and techniques used in order to improve the effectiveness of communication and educational interaction between educators and students in the process of education and teaching in 
schools. In terms of these, facilities need to note the existence of efforts to improve which are as follows [11] :

Deep understanding about the function or usefulness of educational media

Understanding the proper use of educational media in the interaction of teaching

Making simple and easy media

Choosing the right media in accordance with the purpose and content of the material to be taught.

Learning process becomes more standardized in which the media can be used by other teachers in the same class if a teacher cannot attend the class. Interestingly, the subject materials are not merely seen from the content of the materials, but rather how to deliver the material with the media that attract the attention of students in learning in class. The media will attract students' attention to interact with their teachers and classmates. Although the material is hard, it will take less time with creative and innovative media. Learning media are very helpful for teachers to understand the classroom atmosphere. It will be nice to be missed by our students if we can deliver learning materials using good media.

\section{CONCLUSION}

In the digital age, an educator must be expert to create the creative and innovative learning media. The development of time will make students creative in everything so that the educational process will balance. Learning media are tools that can transfer messages or information from an educator to students who aim to facilitate the process of learning in class.

By using of learning media during the process of studying in the classroom, it is expected that the thoughts, feelings, attention and interests of students can be aroused and the students can receive and understand the subject materials from the teachers well.

\section{REFERENCES}

[1] Nurul Usrotun Hasanah, "Peran Media Dalam Pembelajaran," kompasiana, 2015.

[2] M.Ramli, "Media Pembelajaran Dalam Perspektif," J. Kopertais Wil. XI Kalimantan, 2015.

[3] A. Azhar, "Media Pembelajaran," in Media Pembelajaran, 2008.

[4] A. Arsyad, Media Pembelajaran. 2011.

[5] Depdiknas, Media Pembelajaran. Jakarta: Depdiknas, 2003.

[6] Muhaimin, Pemikiran Dan Aktualisasi Pengembangan Pendidikan Islam. JAKARTA: PT. RAJA GRAFINDO PERSADA, 2011.

[7] Oemar Hamalik, Kurikulum dan Pembelajaran. JAKARTA: Bumi Aksara, 2003.

[8] KBBI, KBBI Departemen Pendidikan dan Kebudayaan. Jakarta: Balai Pustaka, 2002.

[9] Juhri Abdul, Landasan dan Wawasan Pendidikan. JAKARTA: Lemlit UM Metro Press, 2009.

[10] A. Azhar, "Media Pembelajaran," Media Pembelajaran, 2008.

[11] Edukasi, "Upaya untuk Meningkatkan Mutu Pendidikan (Peningkatan Mutu Belajar).," kompasiana, 2013. 